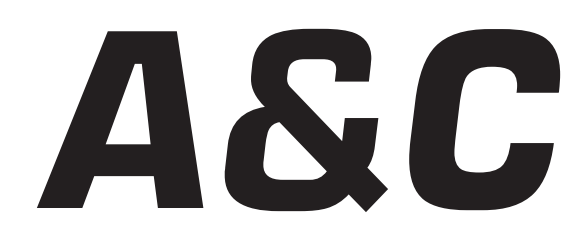

Revista de Direito Administrativo \& Constitucional

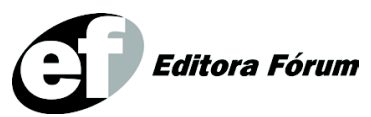

ISSN 1516-3210 


\section{A\&C REVISTA DE DIREITO ADMINISTRATIVO E CONSTITUCIONAL}

IPDA

Instituto Paranaense

de Direito Administrativo

Direção Geral

Romeu Felipe Bacellar Filho

Direção Editorial

Paulo Roberto Ferreira Motta

Direção Executiva

Emerson Gabardo

Conselho de Redação

Edgar Chiuratto Guimarães

Adriana da Costa Ricardo Schier

Célio Heitor Guimarães

\section{Conselho Editorial}

Adilson Abreu Dallari

Alice Gonzáles Borges

Carlos Ari Sundfeld

Carlos Ayres Britto

Carlos Delpiazzo

Cármen Lúcia Antunes Rocha

Celso Antônio Bandeira de Mello

Clèmerson Merlin Clève

Clóvis Beznos

Enrique Silva Cimma

Eros Roberto Grau

Fabrício Motta

Guilhermo Andrés Muñoz (in memoriam)

Jaime Rodríguez-Arana Muñoz

Jorge Luís Salomoni

José Carlos Abraão
José Eduardo Martins Cardoso
José Luís Said
José Mario Serrate Paz
Juan Pablo Cajarville Peruffo
Juarez Freitas
Julio Rodolfo Comadira
Luís Enrique Chase Plate
Lúcia Valle Figueiredo
Manoel de Oliveira Franco Sobrinho
(in memoriam)
Marçal Justen Filho
Marcelo Figueiredo
Márcio Cammarosano
Maria Cristina Cesar de Oliveira

Nelson Figueiredo

Odilon Borges Junior

Pascual Caiella

Paulo Eduardo Garrido Modesto

Paulo Henrique Blasi

Paulo Neves de Carvalho (in memoriam)

Paulo Ricardo Schier

Pedro Paulo de Almeida Dutra

Regina Maria Macedo Nery Ferrari

Rogério Gesta Leal

Rolando Pantoja Bauzá

Sérgio Ferraz

Valmir Pontes Filho

Yara Stropa

Weida Zancaner

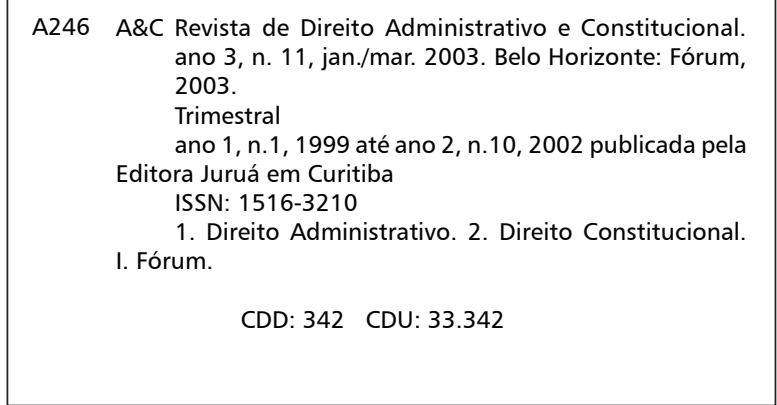

(C) Editora Fórum Ltda. 2007

Todos os direitos reservados. É proibida a reprodução total ou parcial, de qualquer forma ou por qualquer meio eletrônico ou mecânico, inclusive através de processos xerográficos, de fotocópias ou de gravação, sem permissão por escrito do possuidor dos direitos de cópias (Lei nº 9.610, de 19.02.1998).

Editora Fórum Ltda

Av. Afonso Pena, 2770 - 15\%16ª andar - Funcionários

CEP 30130-007 - Belo Horizonte/MG - Brasil

Tel.: 08007043737

Internet: www.editoraforum.com.br

e-mail: editoraforum@editoraforum.com.br
Editor responsável: Luís Cláudio Rodrigues Ferreira Projeto gráfico e diagramação: Luis Alberto Pimenta Revisora: Olga M. A. Sousa

Pesquisa jurídica: Fátima Ribeiro - OAB/MG 74868

Bibliotecária: Alessandra Rodrigues da Silva CRB 2778/MG 6 ${ }^{\text {a Região }}$

Os conceitos e opiniões expressas nos trabalhos assinados são de responsabilidade exclusiva de seus autores.

Impressa no Brasil / Printed in Brazil

Distribuída em todo Território Nacional 


\title{
Ponderação de interesses: acesso ao emprego público versus garantia de proteção contra a despedida arbitrária ou sem justa causa consistente numa indenização. Visão crítica sobre o entendimento do Supremo Tribunal Federal, adotado na ADIn $\mathrm{n}^{\mathrm{o}}$ 1.770-4, a respeito da não extinção do contrato de trabalho do empregado público pela aposentadoria voluntária
}

Luiz Allende-Toha de Lima Bastos
Procurador Federal. Pós-graduando em Direito do Trabalho.

Palavras-chave: Aposentadoria espontânea. Servidor público. Extinção do contrato de trabalho. Justiça do trabalho.

\begin{abstract}
Sumário: 1 Introdução - 2 Acesso ao emprego público - 2.1 O princípio da acessibilidade ao cargo público e emprego público no Direito - 2.2 O princípio de acesso ao cargo e emprego público na Constituição Federal de 1988 - 3 Garantia contra a despedida arbitrária ou sem justa causa consistente numa indenização compensatória - 4 Unidade da Constituição - 5 Decisão do STF na ADIn n ${ }^{\circ} 1.770-4$ sobre a extinção do contrato de trabalho do empregado público pela aposentadoria voluntária - 6 A relação jurídica entre a Administração Pública e o empregado público - 6.1 Empregados públicos - 6.2 Derrogação das normas de Direito Privado às entidades da Administração Indireta - 7 Ponderação de interesses entre o acesso ao emprego público e a proteção contra a despedida arbitrária ou sem justa causa - 7.1 O novo Direito Constitucional - 7.2 A nova interpretação constitucional - 7.3 A ponderação de interesses - 7.4 A identificação do conflito principiológico - 7.5 O princípio da proporcionalidade e a ponderação de interesses - 7.6 O uso da ponderação de interesses na colisão do princípio de acesso ao emprego público versus garantia de proteção contra a despedida arbitrária ou sem justa causa consistente numa indenização - 7.7 Possibilidade de modificação de entendimento do STF - 8 Conclusão - Referências
\end{abstract}




\section{Introdução}

Nada é impossível de mudar. Desconfiai do mais trivial, na aparência singelo. E examinai, sobretudo, o que parece habitual. Suplicamos expressamente: não aceiteis o que é de hábito como coisa natural, pois em tempo de desordem sangrenta, de confusão organizada, de arbitrariedade consciente, de humanidade desumanizada, nada deve parecer natural, nada deve parecer impossível de mudar.

(Bertolt Brecht)

O presente texto refere-se à questão debatida constantemente na Justiça do Trabalho acerca da extinção do contrato de trabalho pela aposentadoria espontânea do empregado público. Recentemente, o Supremo Tribunal Federal (STF) decidiu contrariamente ao Tribunal Superior do Trabalho (TST), entendendo que a aposentadoria espontânea não se encontra elencada dentre as causas motivadoras da rescisão do contrato de trabalho.

A decisão do STF na Ação Direta de Inconstitucionalidade no $1.770-4$ (Relator o Ministro Joaquim Barbosa), a respeito da não extinção do contrato de trabalho do empregado público pela aposentadoria voluntária e declaração da inconstitucionalidade do $\S 1^{\circ}$ do art. 453 da CLT, baseia-se nos fundamentos da proibição de cumulação de vencimentos e proventos e na violação da garantia contra a despedida arbitrária ou sem justa causa consistente numa indenização.

O objetivo geral deste trabalho é discutir a extinção do contrato de trabalho pela aposentadoria voluntária do empregado público. Os objetivos específicos são: a) analisar o julgamento da Ação Direta de Inconstitucionalidade (ADIn $n^{\circ}$ 1.770-4), em que o Supremo Tribunal Federal decidiu pela não extinção do contrato de trabalho pela aposentadoria voluntária do empregado público; b) realizar uma interpretação que possibilite a conciliação entre o princípio do acesso ao emprego público e a garantia de proteção contra a despedida arbitrária ou sem justa causa mediante uma indenização, utilizando a técnica de ponderação de interesses.

\section{Acesso ao emprego público}

2.1 O princípio da acessibilidade ao cargo público e emprego público no Direito

O princípio da acessibilidade aos cargos e empregos públicos

A \& C R. de Dir. Administrativo e Constitucional, Belo Horizonte, ano 7, n. 28, p. 83-113, abr./jun. 2007 
é contemporâneo ao constitucionalismo positivo moderno. A natureza conferida ao princípio da acessibilidade aos cargos públicos no Estado, enquanto direito fundamental expressivo da cidadania (inclusive considerado Direito Político fundamental) e manifestação do princípio da igualdade jurídica, consagrou-se, de maneira definitiva e universal, na Declaração dos Direitos do Homem, proclamada pela ONU em 1948, cujo art. 21 estabelece:

Art. $21^{\circ}: \S 1^{\circ}$ Toda pessoa tem o direito de parte na direção dos negócios públicos de seu país, seja por intermédio de representantes livremente escolhidos.

$\S 2^{\circ}$ Toda pessoa tem o direito de aceder, nas condições de igualdade, às funções públicas de seu país.

$\S 3^{\circ}$ A vontade do povo é o fundamento da autoridade dos poderes públicos; esta vontade deve ser expressa por eleições honestas que devem ter lugar, periodicamente, com sufrágio universal igual e voto secreto ou de acordo com um processo equivalente que assegure a liberdade do voto. (ROCHA, 1999, p. 151)

Duas notas merecem relevância na fórmula que inclui, expressamente, o princípio da acessibilidade a cargos e empregos públicos como sendo fundamentais entre aquelas de primeira geração elencadas na Declaração retrocitada: a primeira refere-se ao direito de aceder a cargos públicos como manifestação do princípio da igualdade jurídica de todos; em seu conteúdo, tem-se a imprescindível supressão de legitimidade de qualquer critério de escolha dos candidatos por fatores externos à sua qualificação pessoal, considerados aqui os elementos internos, tais como: o merecimento em face de sua capacitação pessoal e os seus 'talentos'. Ou seja, tem-se como legítima a escolha do candidato ao provimento de cargos públicos por condição pessoal, e não por condições sociais, econômicas etc. (ROCHA, 1999, p. 151).

A segunda diz respeito à disputa pela vaga na Administração Pública, que deverá ser oferecida de forma igualitária, observando a qualificação pessoal do candidato. E mais, a acessibilidade igual nas "funções públicas de seu país" demonstra uma preocupação de cidadania, sendo considerado um direito fundamental decorrente do desdobramento do Direito Político, de idêntica natureza, de participar da gestão da coisa pública como membro da Administração Pública (ROCHA, 1999, p. 151).

Logo, o alcance dado às "funções públicas de seu país" (expressão declarada nos Direitos do Homem de 1948) não é extensivo aos 
não-cidadãos de um Estado, pois a formação da vontade nacional se faz pelo desempenho dos seus agentes titulares de cargos públicos e ela é direito-dever do cidadão e não dos estrangeiros.

Assim, mostra-se essencial o compromisso do cidadão com a coisa pública de seu Estado e deste com o Direito Fundamental daquele de possibilitar a sua participação na Administração Pública.

\subsection{O princípio de acesso ao cargo e emprego público na Constituição Federal de 1988 \\ Por 'acessibilidade', entende-se o conjunto de normas e princípios} que regulam o ingresso de pessoas interessadas no serviço público. Os parâmetros que regem o acesso ao serviço público acarretam vinculação aos órgãos administrativos, de modo que não pode a Administração Pública criar dificuldades maiores nem abrir ensanchas de facilidades fora das regras que compõem o sistema. Trata-se, então, de verdadeiro Direito subjetivo: o direito de acesso aos cargos, empregos e funções públicas, observadas as normas aplicáveis em cada tipo de provimento (CARVALHO FILHO, 2004, p. 523).

A Constituição Federal de 1988, em sua redação inicial, manteve a mesma estrutura antes adotada, estabelecendo, no inciso I do art. 37, que "os cargos, empregos e funções públicas são acessíveis aos brasileiros que preencham os requisitos estabelecidos em Lei”. A inovação dada foi a extensão do princípio para os empregos e funções públicas, sendo que, na sua promulgação, o termo 'emprego' era previsto para as entidades da Administração Pública Indireta e as expressões ‘cargos e funções públicas’ para as pessoas da Administração Pública Direta.

A Emenda Constitucional no 19/98 alterou o art. 37, I, da Constituição Federal, e ampliou o princípio da acessibilidade também aos estrangeiros. O texto anterior limitava o acesso aos cargos e funções públicas apenas aos brasileiros; essa rigidez criou dificuldades em situações em que se tornava necessário o recrutamento de professores, técnicos e profissionais estrangeiros. Em razão disso, o Constituinte derivado modificou a Constituição.

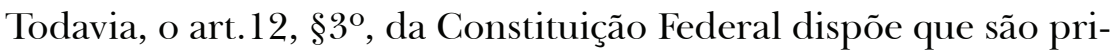
vativos de brasileiros natos os cargos de presidente e vice-presidente da República, de presidente da Câmara dos Deputados, de presidente do

A \& C R. de Dir. Administrativo e Constitucional, Belo Horizonte, ano 7, n. 28, p. 83-113, abr./jun. 2007 
Senado Federal, de ministro do Supremo Tribunal Federal, da carreira diplomática e de oficial das Forças Armadas. A Constituição exige, ainda, para os cargos públicos políticos, aqueles cujo provimento se dão a partir

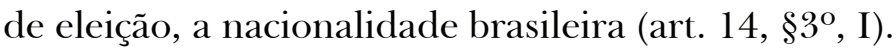

Excepciona-se, no sistema constitucional vigente, a submissão aos requisitos infraconstitucionais, quanto à nacionalidade, para os portugueses com residência permanente no Brasil, aos quais "serão atribuídos os direitos inerentes aos brasileiros, [...] se houver reciprocidade em favor dos brasileiros" (art. 12, §1 ${ }^{\circ}$ ). Entendeu-se, desde a promulgação da Lei Fundamental de 1988 (com alteração promovida pela Emenda Constitucional $n^{\circ} 3 / 93$ ), que contempla a hipótese que a nacionalidade estrangeira não impede os portugueses de acederem a cargo público, desde que comprovem o cumprimento das condições constitucionais estabelecidas e aquelas que também os brasileiros têm de demonstrar quanto ao cargo no qual se apresentem como candidatos ao provimento. Não se tem modificação na interpretação e na aplicação dessa norma pela reforma veiculada pela Emenda Constitucional n ${ }^{\circ}$ 19/98 (ROCHA, 1999, p. 158).

O artigo 37, II, da Constituição Federal, com redação dada pela Emenda Constitucional no 19 , preceitua que:

[...] a investidura em cargo ou emprego público depende de aprovação prévia em concurso público de provas ou de provas e títulos, de acordo com a natureza e a complexidade do cargo ou emprego, na forma prevista em lei, ressalvadas as nomeações para cargo em comissão declarado em lei de livre nomeação e exoneração.

Dessarte, é necessário concurso para ingressar no serviço público (lato sensu). O concurso de ingresso é o procedimento administrativo posto à disposição da Administração Pública Direta, autárquica, fundacional ou empresarial, de qualquer nível do governo, para a seleção do futuro melhor titular de cargo ou emprego público, necessário à execução de serviços sob sua respectiva responsabilidade. Três são os fundamentos que legitimam a exigência do concurso de ingresso de pessoal na Administração Pública Direta, autárquica, fundacional e empresarial, de qualquer nível de governo: principiológico, constitucional e legal. Embora outros possam servir de suporte para a obrigatória realização desse certame, é nos princípios da igualdade e moralidade administrativa que está o mais relevante dos seus fundamentos (GASPARINI, 2005, p. 20-21). 


\section{Garantia contra a despedida arbitrária ou sem justa causa consistente numa indenização compensatória}

Entre os direitos do trabalhador, a Constituição Federal de 1988, no art. $7^{\circ}$, I, assegura: "a relação de emprego protegida contra a despedida arbitrária ou sem justa causa, nos termos de lei complementar, que preverá indenização compensatória, dentre outros direitos;"

Vê-se que o direito à estabilidade no emprego cedeu lugar, a partir de 1988, a uma proteção contra despedida arbitrária ou sem justa causa, consistente numa indenização compensatória, entre outros direitos, a serem disciplinados em Lei Complementar.

O art. 10 do Ato das Disposições Constitucionais Transitórias (ADTC) previu, até que fosse promulgada a Lei Complementar a que se refere o art. $7^{\circ}$ da Constituição, uma indenização a ser paga ao empregado no caso de dispensa arbitrária ou sem justa causa, devendo ser considerada, para este efeito, toda ruptura contratual que não se fundar em falta grave ou em motivos técnicos ou de ordem econômico-financeira, consoante disposto nos arts. 482 e 165 da Consolidação das Leis do Trabalho (CLT).

Portanto, no estágio atual da nossa legislação, o trabalhador de empresa privada não é destinatário de tutela quanto à ocupação, sendo a dispensa um direito potestativo do empregador, salvo se, à época da promulgação da Constituição Federal (5 de outubro de 1988), o empregado já fosse amparado pela estabilidade prevista no art. 492 da CLT (BARROS, 2005, p. 920).

O Supremo Tribunal Federal, no julgamento da cautelar da ADIn $\mathrm{n}^{\mathrm{o}} 1.721$ (que discute a possibilidade de extinção do contrato de trabalho pela aposentadoria voluntária), consignou expressamente a garantia de proteção contra a despedida arbitrária ou sem justa causa mediante uma indenização compensatória, nos seguintes termos:

Ação Direta de Inconstitucionalidade. Art. $3^{\circ}$ da MP n ${ }^{\circ}$ 1.596-14/97 (convertida na Lei $n^{\circ} 9.528 / 97$ ), na parte em que incluiu $\S 2^{\circ}$ no art. 453 da CLT. Alegada ofensa à Constituição.

O direito à estabilidade no emprego cedeu lugar, com a Constituição de 1988 (art. $\left.7^{\circ}, \mathrm{I}\right)$, a uma proteção contra despedida arbitrária ou sem justa causa, consistente em uma indenização compensatória, entre outros direitos, a serem estipulados em lei complementar. A eficácia do dispositivo não ficou condicionada à edição da referida lei, posto haver sido estabelecida, no art. 10 do ADCT, uma multa a ser aplicada de pronto até a promulgação do referido diploma normativo (art. 10 do ADCT), havendo-se de considerar arbitrária e sem justa 
causa, para tal efeito, toda despedida que não se fundar em falta grave ou em motivos técnicos ou de ordem econômico-financeira, a teor do disposto nos arts. 482 e 165 da CLT. O diploma normativo impugnado, todavia, ao dispor que a aposentadoria concedida a empregado que não tiver completado 35 anos de serviço (aposentadoria proporcional por tempo de serviço) importa extinção do vínculo empregatício - efeito que o instituto até então não produzia —, na verdade, outra coisa não fez senão criar modalidade de despedida arbitrária ou sem justa causa, sem indenização, o que não poderia ter feito sem ofensa ao dispositivo constitucional sob enfoque. Presença dos requisitos de relevância do fundamento do pedido e da conveniência de pronta suspensão da eficácia do dispositivo impugnado. Cautelar deferida. (ADI-MC 1721/DF - Distrito Federal- Medida Cautelar na Ação Direta de Inconstitucionalidade. Relator: Ministro Ilmar Galvão. Julgamento: 19 dez. 1997. Órgão Julgador: Tribunal Pleno. Publicação: DJ, 11 abr. 2003. Ementa, v. 02106-01, p. 00088).

Dessa forma, entendeu a Suprema Corte que haveria ofensa ao dispositivo constitucional que garante uma proteção contra despedida arbitrária ou sem justa causa, consistente em uma indenização compensatória, entre outros direitos, a serem estabelecidos em Lei Complementar (art. $7^{\circ}$, I e art. 10 do ADCT), na hipótese de consideração de extinção do contrato de trabalho pela aposentadoria voluntária do empregado da iniciativa privada sem o pagamento da indenização pela despedida sem justa causa.

Diante disso, o STF concluiu que não há rescisão contratual do empregado que tem deferido a sua aposentadoria voluntária, fazendo jus a uma indenização pela despedida imotivada.

\section{Unidade da Constituição}

A Unidade da Constituição é um princípio interpretativo que significa que o direito constitucional deve ser interpretado de forma a evitar contradições entre as suas normas e, sobretudo, entre os princípios jurídicopolíticos constitucionalmente estruturantes.

Um ordenamento jurídico só pode ser concebido como um conjunto de normas. Vale dizer que é condição da existência de uma ordem jurídica a concorrência de normas. Não obstante, a pluralidade de normas jurídicas que abrange esse ordenamento constitui uma unidade, quer porque suas normas nascem de mesma fonte (ordenamento simples), quer porque suas normas, ainda que nascidas de fontes distintas tenham o mesmo fundamento de validade (ordenamento complexo) (BOBBIO, 1999, p. 48-49). 
Toda Constituição deve ser compreendida como uma unidade e como um sistema que privilegia determinados valores sociais. A Constituição é, portanto, a fonte máxima de produção de todo o Direito e último fundamento de validade das normas jurídicas, que confere unidade de caráter sistemático ao ordenamento jurídico. Mas ela própria representa uma unidade normativa, enquanto ordem unitária da vida política e social da ossatura estatal. Isso implica em afirmar que toda Constituição deve ser compreendida como uma unidade e como um sistema que privilegia determinados valores (PIOVESAN, 2002, p. 25).

Essa unidade normativa pressupõe a inexistência de hierarquia normativa ou formal entre as normas constitucionais, sem qualquer distinção entre normas materiais ou formais ou entre normas-princípios e normas-regras, uma vez que as normas constitucionais são frutos de uma vontade unitária e gerada simultaneamente (BARROSO, 1996, p. 187).

A unidade normativa da Constituição é importante, na medida em que o descumprimento de uma norma constitucional põe em perigo a própria unidade do texto magno. Logo, a garantia da supremacia de uma norma constitucional proporciona a garantia da própria Constituição. Assim, toda e qualquer exegese da Carta Magna deve levar em consideração o princípio da unidade normativa (CUNHA JÚNIOR, 2006, p. 32-33).

O princípio da unidade obriga o intérprete a considerar a constituição na sua globalidade e a harmonizar os espaços de tensão existentes entre as normas constitucionais a concretizar. Assim, em face do princípio da unidade, todas as disposições constitucionais têm a mesma hierarquia e devem ser interpretadas de forma harmônica.

\section{Decisão do STF na ADIn n ${ }^{0} 1.770-4$ sobre a extinção do contrato de trabalho do empregado público pela aposentadoria voluntária}

O presente tema foi objeto de análise pelo Supremo Tribunal Federal no julgamento da ADIn $\mathrm{n}^{\circ} 1.770-4$ sobre a constitucionalidade do $\S 1^{\circ}$ do art. 453 da CLT (acrescentado pela Lei $\mathrm{n}^{\circ}$ 9.528/1997), que previa a readmissão do empregado público aposentado voluntariamente.

Dispunha o art. 453 da CLT, verbatim:

$\S 1^{\circ} \mathrm{Na}$ aposentadoria espontânea de empregados das empresas públicas e sociedades de economia mista é permitida sua readmissão desde que atendidos aos requisitos constantes do art. 37, inciso XVI, da Constituição, e condicionada à prestação de concurso público.

A \& C R. de Dir. Administrativo e Constitucional, Belo Horizonte, ano 7, n. 28, p. 83-113, abr./jun. 2007 
A respeito, pronunciou-se o $\mathrm{STF}$ nos seguintes termos:

AÇÃO DIRETA DE INCONSTITUCIONALIDADE. READMISSÃO DE EMPREGADOS DE EMPRESAS PÚBLICAS E SOCIEDADES DE ECONOMIA MISTA. ACUMULAÇÃO DE PROVENTOS E VENCIMENTOS. EXTINÇÃO DO VÍNCULO EMPREGATÍCIO POR APOSENTADORIA ESPONTÂNEA. NÃO-CONHECIMENTO. INCONSTITUCIONALIDADE.

Lei 9.528/1997, que dá nova redação ao $§ 1^{\circ}$ do art. 453 da Consolidação das Leis do Trabalho - CLT -, prevendo a possibilidade de readmissão de empregado de empresa pública e sociedade de economia mista aposentado espontaneamente. Art. 11 da mesma lei, que estabelece regra de transição. Não se conhece de ação direta de inconstitucionalidade na parte que impugna dispositivos cujos efeitos já se exauriram no tempo, no caso, o art. 11 e parágrafos. É inconstitucional o $\S 1^{\circ}$ do art. 453 da CLT, com a redação dada pela Lei $9.528 / 1997$, quer porque permite, como regra, a acumulação de proventos e vencimentos — vedada pela jurisprudência do Supremo Tribunal Federal —, quer porque se funda na idéia de que a aposentadoria espontânea rompe o vínculo empregatício.

Pedido não conhecido quanto ao art. 11, e parágrafos, da Lei no 9.528/1997. Ação conhecida quanto ao $\S 1^{\circ}$ do art. 453 da Consolidação das Leis do Trabalho, na redação dada pelo art. $3^{\circ}$ da mesma Lei 9.528/1997, para declarar sua inconstitucionalidade. (ADIn $n^{\circ}$ 1.770-4. Órgão julgador: Tribunal Pleno, 11 out. 2006).

Relatou o Ministro Joaquim Barbosa na mencionada ADIn como fundamentos para a decisão:

\section{$(\ldots)$}

O raciocínio do ministro Moreira Alves parece-me isento de críticas. Ao menos desde o julgamento do RE 163.204 (rel. Min. Carlos Velloso), a Corte tem decidido, já depois do advento da Constituição de 1988, que é vedada a acumulação de proventos de aposentadoria com vencimentos, a não ser nos casos excepcionalmente previstos no art. 37, XVI e XVII, da Carta. É preciso lembrar que a rationale em que se baseou o Pleno partiu do pressuposto de que a vedação de acumulação também se aplica aos empregados de empresas públicas e sociedades de economia mista - daí por que a explícita referência, na ementa do julgado, ao inciso XVII do art. 37. Vale lembrar que o entendimento do Tribunal foi confirmado com o advento da Emenda Constitucional $n^{\circ} 20$, que taxativamente vedou o tipo de acumulação ora em questão ao acrescentar o $\S 10$ ao art. 40 da Carta de 1988, sem contar os reiterados pronunciamentos da Casa no mesmo sentido (cf., v.g., RE 463.028, rel. Min. Ellen Gracie, Segunda Turma; AI 484.756-AgR, rel. Min. Carlos Velloso, Segunda Turma; ADI 1.328, rel. Min. Ellen Gracie; RE 141.376, rel. Min. Néri da Silveira, Segunda Turma, e RE 197.699, rel. Min. Marco Aurélio). Supremo Tribunal Federal Mantido incólume, o dispositivo impugnado cria a possibilidade de acumulação de proventos e vencimentos. Voltemos a ele:

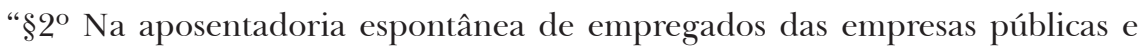
sociedades de economia mista é permitida sua readmissão desde que atendidos aos requisitos constantes do art. 37, inciso XVI, da Constituição, e condicionada 
à prestação de concurso público."

A inconstitucionalidade do dispositivo está em permitir, como regra, a readmissão do empregado aposentado espontaneamente, de modo a possibilitar a acumulação de proventos e vencimentos. Na verdade, segundo a orientação desta Corte, acumulação dessa índole somente pode ser vedada, e não permitida. Ainda que o próprio dispositivo estabeleça que a readmissão está condicionada ao preenchimento dos requisitos do inciso XVI do art. 37, isso não valida a norma, porque o inciso XVI somente atua no campo da exceção, e não no da regra. A regra continua sendo a vedação ao acúmulo de proventos e vencimentos, o que é flagrantemente contrariado pela primeira parte do $\S 1^{\circ}$ do art. 453 .

De outro lado, é curioso notar que a norma impugnada apenas se refere ao inciso XVI do art. 37 — que veda a acumulação de cargos públicos —, e não ao inciso XVII do mesmo artigo - que Supremo Tribunal Federal estende a proibição de acumulação a entidades como empresas públicas e sociedades de economia mista.

Ademais, mesmo a referência ao art. 37, XVI, é inútil, porque tal disposição faz parte da própria Constituição, que obviamente se sobrepõe à CLT. Na pouco freqüente situação de um aposentado ser readmitido como professor ou profissional de saúde empregado de empresa pública e sociedade de economia mista, os incisos XVI e XVII do art. 37, por si sós, independentemente do $\$ 1^{\circ}$ do art. 453, já lhe trarão proteção.

Há, portanto, inconstitucionalidade na norma atacada, por permitir algo que esta Corte tem entendido que a Constituição veda: a acumulação de proventos com vencimentos.

Evidentemente, esse juízo de inconstitucionalidade não atinge a situação dos servidores amparados pelo art. 11 da Emenda Constitucional n ${ }^{\circ}$ 20, a qual permite, desde que observados certos critérios, a acumulação de proventos e vencimentos. Também se pode vislumbrar inconstitucionalidade no $\S 1^{\circ}$ do art. 453, se se considerar, como considerou esta Corte no julgamento da ADI 1.721 (rel. Min. Ilmar Galvão), que a aposentadoria espontânea não rompe o vínculo empregatício.

Na dicção da maioria da Corte naquele julgado, o $§ 2^{\circ}$ do art. 453 da CLT aplicado aos empregados da iniciativa privada - funda-se na idéia de que a aposentadoria espontânea rompe o vínculo empregatício, o que seria vedado pela Constituição de 1988, dado seu efeito de despedida arbitrária ou sem justa causa, sem indenização.

Levando-se em conta também essa perspectiva, haveria inconstitucionalidade no $\S 1^{\circ}$ do art. 453 da CLT, porquanto fundado nas mesmas premissas em que elaborado o $\$ 2^{\circ}$ do mesmo dispositivo: o de que a aposentadoria espontânea do empregado, no caso, de empresa pública ou sociedade de economia mista gera o rompimento do vínculo empregatício, o que traz como conseqüência a despedida arbitrária ou sem justa causa, não tendo o empregado nenhum direito à indenização.

Por essas razões, voto no sentido de confirmar o julgamento liminar, para não conhecer do pedido quanto ao art. 11, e parágrafos, da Lei 9.528/1997 e, conhecendo da ação quanto ao $\S 1^{\circ}$ do art. 453 da CLT, na redação dada pelo art. $3^{\circ}$ da mesma Lei 9.528/1997, declarar sua inconstitucionalidade. (grifou-se)

Denota-se, pois, do voto condutor do julgamento da ADIn n ${ }^{\circ} 1.770-$ 
4 , os fundamentos adotados para a inconstitucionalidade do $\S 1^{\circ}$ do art. 453 da CLT (que permitia a recondução de empregado público por novo concurso e explicitava que a aposentadoria voluntária era uma forma de extinção do contrato de trabalho) foram os seguintes:

a) proibição de acumulação de vencimentos com proventos (artigos 37, XVI e XVII da CF/88);

b) violação da garantia contra a despedida arbitrária ou sem justa causa sem o pagamento da indenização ao empregado (art. 7, I, e art. 10 da ADCT da CF/88).

Todavia, conforme será demonstrado nos próximos tópicos, a interpretação mais coerente desses artigos com os dispositivos constitucionais deve ser outra.

No caso dos empregados públicos, a interpretação dada pelo Supremo Tribunal Federal deve ser diferente daquela dada para os empregados da iniciativa privada (ADIn $\mathrm{n}^{\circ} 1.721-3$ ), que concluiu pela impossibilidade de rescisão contratual do emprego pela aposentadoria voluntária. Isso porque deve prevalecer o princípio de acesso aos cargos e empregos públicos (art. 37, I e II da CF/88) frente à garantia a uma indenização nas hipóteses de despedidas arbitrárias e sem justa causa (art. 7, I, CF/88 e art. 10 do ADCT).

\section{A relação jurídica entre a Administração Pública e o empregado público}

\subsection{Empregados públicos}

Empregos públicos são núcleos de encargos de trabalho permanentes a serem preenchidos por agentes contratados para desempenhá-los, sob relação trabalhista. De acordo com o art. 61, §1 ${ }^{\circ}$, II, “a”, da CF/88, os empregos permanentes na Administração Direta ou em autarquia somente podem ser criados por Lei.

Nas pessoas de Direito Público (União, Estados, Municípios, Distrito Federal, autarquias e fundações de Direito Público), há servidores titulares de cargos e ocupantes de empregos. Todavia, nas Pessoas Jurídicas de Direito Privado da Administração Indireta (empresas públicas e sociedades de economia mista e fundações governamentais de Direito Privado), existem tão-somente empregos públicos.

O regime dos trabalhadores de sociedade de economia mista, de empresas públicas e de fundações de Direito Privado, instituídas pelo Poder Público, será necessariamente o da Consolidação das Leis do 
Trabalho, e jamais o estatutário (aplicável apenas aos ocupantes de cargos públicos). Com efeito, a CF/88 (art. 173, §1º, II) possui expressa disposição estabelecendo o regime trabalhista para os servidores das entidades estatais que exploram atividades econômicas.

Embora os empregados públicos sujeitem-se as normas previstas na CLT, sofrem influências advindas da natureza governamental da contratante.

De fato, não obstante a relação entre o Poder Público e seus empregados ser contratual e basicamente regida pelas normas celetistas, está sujeita a disposições constitucionais que, por dizerem respeito a quaisquer servidores públicos, introduzem particularidades no regime trabalhista aplicável aos empregados do Poder Público.

\subsection{Derrogação das normas de Direito Privado às entidades da Administração Indireta}

Com relação aos servidores públicos das entidades da Administração Indireta, há várias normas constitucionais que dispõem sobre o assunto. O artigo 173, § $1^{\circ}$, II (na redação dada pela Emenda Constitucional $\left.n^{\circ} 19 / 98\right)$, impõe a sujeição às normas trabalhistas aos empregados das empresas públicas, sociedades de economia mista e suas subsidiárias que explorem atividade econômica de produção ou comercialização de bens ou de prestação de serviços.

Todavia, a própria Constituição, no capítulo concernente à Administração Pública (art. 37), derroga parcialmente a legislação trabalhista, ao dispor normas que se aplicam a todos os servidores da Administração Pública Direta ou Indireta, merecendo destaque: a exigência de concurso público para ingresso; proibição de acumulação de cargos, empregos e funções (com as exceções previstas na própria Constituição).

Além disso, as entidades da Administração Indireta estão sujeitas à restrição do art. 169, $\S 1^{\circ}$ (redação da Emenda Constitucional n ${ }^{\circ} 19 / 98$ ), segundo o qual, conforme Di Pietro (2006, p. 446):

[...] a concessão de vantagem ou aumento de remuneração, a criação de cargos, empregos e funções ou alteração de estrutura de carreiras, bem como a admissão ou contratação de pessoal, a qualquer título, pelos órgãos da administração direta ou indireta, inclusive fundações instituídas e mantidas pelo poder público, só poderão ser feitas: I - se houver autorização específica na lei de diretrizes orçamentárias, ressalvadas as empresas públicas e as sociedades de economia mista.

A \& C R. de Dir. Administrativo e Constitucional, Belo Horizonte, ano 7, n. 28, p. 83-113, abr./jun. 2007 
De acordo com Di Pietro (2006, p. 417), quando o Estado cria uma Pessoa Jurídica Privada, ela aparece com praticamente todas as características indicadas para as Pessoas Públicas: elas são criadas e extintas pelo Poder Público; o seu fim principal não é o lucro; elas não podem afastar-se dos fins para os quais foram instituídas; elas sujeitam-se a controle positivo do Estado; e recebem, às vezes, algumas prerrogativas autoritárias. Então, segundo a autora, é compreensível que assim seja: se o Estado necessita de uma Pessoa Jurídica para exercer determinada atividade, ele a coloca no mundo jurídico e dele retira quando lhe pareça conveniente ao interesse coletivo. Ele verifica os fins que ela deve perseguir, sem os quais não se justificaria a sua existência. Para obrigá-la a cumprir seus fins, o Estado exerce sobre a Pessoa Jurídica o controle estabelecido em lei. E, ainda, para que ela atinja a esses fins, o Estado lhe outorga, na medida em que sejam necessários, determinados privilégios próprios do Poder Público.

A Administração Pública ao instituir, com autorização da lei, empresas públicas, sociedades de economia mista ou fundações de direito privado, está se socorrendo de meios de atuação próprios do Direito Privado. Isso porque foi o regime jurídico de Direito Privado que levou o Poder Público a adotar esse tipo de entidade para poder atuar com maior liberdade do que a Administração Pública Direta.

Entretanto, tais pessoas jurídicas de direito privado nunca se sujeitam inteiramente ao Direito Privado, pois o seu regime jurídico é híbrido, porque, sob muitos aspectos, elas se submetem à vontade do ente estatal, que as criou, para atingir determinado fim de interesse público.

Sendo o interesse público indisponível e sempre predominante sobre o particular, a adoção pura e simples do regime jurídico privado seria inaceitável, porque retiraria das entidades da Administração Indireta determinadas prerrogativas que lhes são reconhecidas precisamente para permitir a consecução de seus fins; do mesmo modo que, ao lhes permitir atuar com autonomia de vontade, própria do Direito Privado, suprimirse-iam as restrições legais que o Direito Público impõe e que constituem a garantia fundamental da moralidade administrativa e do respeito aos direitos dos administrados. As normas de Direito Público, que derrogam parcialmente o Direito Privado, têm por objetivo assegurar o equilíbrio entre a posição de supremacia da Administração e a liberdade de atuação que caracteriza as Pessoas Jurídicas de Direito Privado. Melhor dizendo, 
a Administração Pública confere às suas Pessoas Jurídicas Privadas os meios de atuação do Direito Privado, considerados mais adequados para a execução de determinadas atividades; mas, simultaneamente, as submete, em parte, ao regime administrativo, na medida considerada essencial para a consecução daqueles mesmos fins (DI PIETRO, 2006, p. 418-419).

Assim, em todas as Pessoas de Direito Privado criadas pelo Estado existe a derrogação parcial do Direito Privado pelas normas de Direito Público.

\section{Ponderação de interesses entre o acesso ao emprego público e a proteção contra a despedida arbitrária ou sem justa causa}

\subsection{O novo Direito Constitucional}

O novo Direito Constitucional ou Neoconstitucionalismo desenvolveu-se na Europa, ao longo da segunda metade do século XX, e, no Brasil, após a Constituição de 1988. O ambiente filosófico em que ele floresceu foi o do pós-positivismo, tendo como principais mudanças de paradigma, no plano teórico, o reconhecimento de força normativa à Constituição, a expansão da jurisdição constitucional e a elaboração das diferentes categorias da nova interpretação constitucional (BARROSO, 2007, p. 249).

A constitucionalização do Direito importa em aplicação dos valores dispostos nos princípios e regras da Constituição por todo o sistema jurídico, especialmente pela via do controle constitucional das normas, em suas diversas formas (controle difuso e o controle concentrado) para conformar o seu sentido e o alcance.

A constitucionalização, o aumento da demanda por justiça por parte da sociedade brasileira, a ascensão institucional do Poder Judiciário provocaram uma imensa judicialização das relações políticas e sociais. Tal fato potencializa a importância do debate, na teoria constitucional, acerca do equilíbrio que deve haver entre supremacia constitucional, interpretação judicial da Constituição e processo político majoritário. As circunstâncias brasileiras, na quadra atual, reforçam o papel do Supremo Tribunal Federal, inclusive em razão da crise de legitimidade por que passam o Legislativo e o Executivo, não apenas como fenômeno conjuntural, mas como crônica disfunção institucional (BARROSO, 2007, p. 249).

\subsection{A nova interpretação constitucional}

A nova interpretação constitucional está ligada ao desenvolvimento A \& C R. de Dir. Administrativo e Constitucional, Belo Horizonte, ano 7, n. 28, p. 83-113, abr./jun. 2007 
de novas fórmulas de realização da vontade da Constituição, sendo que não é desprezado o método tradicional de aplicação das regras jurídicas referente a subsunção dos fatos a norma, bem como dos métodos tradicionais da hermenêutica: gramatical, histórico, sistemático e teleológico. Pelo contrário, tais métodos continuam sendo importantes na busca da solução de casos concretos.

Todavia, nem sempre suficientes. Mesmo no quadro da dogmática jurídica tradicional, já haviam sido sistematizados diversos princípios específicos de interpretações constitucionais aptos a superar as limitações das interpretações jurídicas convencionais, concebidas, sobretudo, em função da legislação infraconstitucional, e mais especialmente do Direito Civil (BARROSO, 2005, p. 81-82).

Segundo Barroso (2005, p. 81-82), a grande virada na interpretação constitucional ocorreu a partir da difusão de uma constatação que, além de singela, sequer era original: não é verdadeira a crença de que as normas jurídicas em geral - e as constitucionais em particular — tragam sempre em si um sentido único e objetivo; caberia ao intérprete uma atividade de mera revelação do conteúdo preexistente na norma, sem desempenhar qualquer papel criativo na sua concretização.

De fato, a técnica legislativa, ao longo do século XX, passou a utilizar, crescentemente, cláusulas abertas ou conceitos indeterminados, como dano moral, justa indenização, ordem pública, melhor interesse do menor, boafé. Por essa fórmula, o ordenamento jurídico passou a transferir parte da competência decisória do legislador para o intérprete. A Lei fornece parâmetros, mas somente à luz do caso concreto, dos elementos subjetivos e objetivos a ele relacionados, tal como apreendidos pelo aplicador do Direito, será possível a determinação da vontade legal. O juiz, portanto, passou a exercer uma função claramente integradora da norma e complementando-a com sua própria valoração (BARROSO, 2005, p. 82).

A ascensão dos princípios sobreveio à seqüência histórica, cuja carga axiológica e dimensão ética conquistaram, finalmente, eficácia jurídica e aplicabilidade direta e imediata. Princípios e regras passaram a desfrutar do mesmo status de norma jurídica, sem embargo de serem distintos no conteúdo, na estrutura normativa e na aplicação (BARROSO, 2005, p. 82).

Para Barroso, de maneira geral, 'regras' são relatos objetivos, descritivos de determinadas condutas e aplicáveis a um conjunto delimitado de situações. Ocorrendo a hipótese prevista no seu relato, a regra deve incidir, pelo mecanismo tradicional da subsunção: enquadram-se os fatos 
na previsão abstrata e produz-se uma conclusão. A aplicação de uma regra se opera na modalidade tudo ou nada: ou ela regula a matéria em sua inteireza ou é descumprida. Na hipótese do conflito entre duas regras, só uma será válida e irá prevalecer (2005, p. 82).

Já 'princípios', segundo Alexy (2007, p. 295), são normas que ordenam que algo seja realizado na maior medida possível, dentro das possibilidades jurídicas reais existentes. Por isso, são mandados de otimização, caracterizados pelo fato de que podem ser cumpridos em diferentes graus e que a medida de seu cumprimento não só depende das possibilidades reais, mas também das jurídicas. Barroso (2005, p. 84) acrescenta: em uma ordem democrática, princípios com freqüência entram em tensão dialética, apontando direções diversas, por concessões recíprocas. Sua aplicação, portanto, não será no esquema tudo ou nada, mas graduada à vista das circunstâncias representadas por outras normas ou por situações de fato.

Princípios e direitos previstos na Constituição entram muitas vezes em linha de colisão, por abrigarem valores contrapostos e igualmente relevantes, por exemplo: livre iniciativa e proteção do consumidor; direito de propriedade e função social da propriedade; segurança pública e liberdades individuais; direitos da personalidade e liberdade de expressão. O que caracteriza esse tipo de situação jurídica é a ausência de uma solução em tese para o conflito, fornecida abstratamente pelas normas jurídicas aplicáveis (BARROSO, 2005, p. 84).

$\mathrm{Na}$ aplicação dos princípios, o intérprete irá determinar, in concreto, quais são as condutas aptas a realizá-los adequadamente. Nos casos de colisão de princípios ou de direitos fundamentais, caberá a ele fazer as valorações adequadas, de modo a preservar o máximo da cada um dos valores em conflito, realizando escolhas acerca de qual interesse deverá circunstancialmente prevalecer. Um intérprete que faz valorações e escolhas, não desempenha apenas uma função de conhecimento, mas exerce uma certa discricionariedade. Todavia, suas decisões, para que não sejam arbitrárias, deverão ser racionais, argumentativas e fundamentadas.

Assim sendo, a moderna interpretação constitucional diferencia-se da tradicional em razão de que a norma em abstrato não possui primazia; sendo que o problema passa a ser resolvido pela aplicação técnica de subsunção dos fatos com a norma, bem como pela ponderação de interesses na aplicação dos princípios constitucionais. O intérprete terá de

A \& C R. de Dir. Administrativo e Constitucional, Belo Horizonte, ano 7, n. 28, p. 83-113, abr./jun. 2007 
se servir dos elementos da teoria da argumentação, para explicar a solução constitucionalmente adequada para a questão que lhe foi posta.

\subsection{A ponderação de interesses}

O pluralismo de idéias existente na sociedade projeta-se na Constituição, que acolhe, através dos seus princípios, valores e interesses dos mais diversos matizes. Tais princípios, vistos no decorrer deste estudo, entram, às vezes, em tensão na solução de casos concretos. Tal como observou Karl Engish apud Sarmento (2003, p. 97), a contradição principiológica é um fenômeno inevitável, na medida em que constitui reflexo natural das "desarmonias que surgem numa ordem jurídica pelo fato de, na constituição desta, tomarem parte diferentes idéias fundamentais entre as quais se pode estabelecer conflito".

Segundo Barcellos (2003, p. 55), a ponderação pode ser descrita como uma técnica de decisão própria para casos difíceis (do inglês hard cases), em relação aos quais o raciocínio tradicional da subsunção não é adequado. A estrutura geral da subsunção pode ser descrita da seguinte forma: premissa maior - enunciado normativo - incidindo sobre a premissa menor - fatos - , produzindo, como conseqüência, a aplicação da norma ao caso concreto. O que ocorre comumente nos caso difíceis, porém, é que convivem, postulando aplicação, diversas premissas maiores igualmente válidas e de mesma hierarquia; estas, todavia, indicam soluções normativas diversas e muitas vezes contraditórias. A subsunção não tem instrumentos para produzir uma conclusão que seja de considerar todos os elementos normativos pertinentes; sua lógica tentará isolar uma única norma para o caso. Dessa maneira, a ponderação de interesses consiste no método utilizado para a resolução desses conflitos constitucionais.

Quando se interpreta a Constituição, não é possível simplesmente escolher uma norma em detrimento das demais: o princípio da unidade, pelo qual todas as disposições constitucionais têm a mesma hierarquia e devem ser interpretadas de forma harmônica, não admite tal solução. Situação semelhante ocorre com muitas normas infraconstitucionais que, refletindo os conflitos internos da Constituição, encontram suporte lógico e axiológico em algumas normas constitucionais, mas parecem afrontar outras. Também aqui a verificação da constitucionalidade dessas normas infraconstitucionais não poderá ser resolvida por uma mera subsunção (BARCELLOS, 2003, p. 55-56). 
Tal técnica caracteriza-se pela sua preocupação com a análise do caso concreto em que ocorreu o conflito, porquanto as situações fáticas do problema enfrentado necessitam de uma atribuição do 'peso específico' a cada princípio em confronto, sendo, por conseqüência, imprescindíveis à definição do resultado da ponderação.

A relevância conferida às dimensões fáticas do problema concreto, porém, não pode jamais implicar na desconsideração do dado normativo, que também se revela absolutamente vital para a resolução das tensões entre princípios constitucionais. Afinal, a Constituição é, antes de tudo, norma jurídica, e desprezar a sua força normativa é desproteger o cidadão da sua garantia jurídica mais fundamental, como afirmou Barroso apud Sarmento (2003, p. 97-98): "em matéria constitucional, é importante que se diga, o apego ao texto positivado não importa em reduzir o direito à norma, mas, ao contrário, em elevá-lo à condição de norma, pois ele tem sido menos do que isso".

Dessarte, os principais casos de aplicação da ponderação de interesses são aqueles nos quais se identificam confrontos de razões, de interesses, de valores ou de bens acolhidos por normas constitucionais. A razão da ponderação de interesses é solucionar esses conflitos normativos da maneira menos perturbadora para o sistema como um todo, de modo que as normas em oposição continuem a conviver, sem a negação de qualquer delas, ainda que em determinado caso concreto elas possam ser aplicadas em intensidades diferentes.

\subsection{A identificação do conflito principiológico}

Segundo Sarmento (2003, p. 99), a ponderação de interesses só se torna necessária quando, de fato, estiver caracterizada a colisão entre pelo menos dois princípios constitucionais incidentes sobre um caso concreto. Assim, a primeira tarefa que se impõe ao intérprete, diante de uma possível ponderação, é a de proceder à interpretação dos cânones envolvidos, para verificar se eles efetivamente se confrontam na resolução do caso, ou se, ao contrário, é possível harmonizá-los.

Nessa tarefa, estará o exegeta dando cumprimento ao princípio da unidade da Constituição, que lhe demanda o esforço de buscar a conciliação entre normas constitucionais aparentemente conflitantes, evitando as antinomias e colisões. Isso porque a Constituição não representa um aglomerado de normas isoladas, mas um sistema orgânico, no qual 
cada parte tem de ser compreendida à luz das demais. Como ressaltou Canotilho apud Sarmento (2003, p. 99-100), “o princípio da unidade obriga o intérprete a considerar a constituição em sua globalidade e a procurar harmonizar os espaços de tensão entre as normas constitucionais a concretizar".

Daí porque o exegeta deve buscar a definição do campo normativo de cada princípio em conflito, para verificar se a hipótese está realmente contida no âmbito de tutela de mais de um deles.

No campo dos direitos fundamentais, esta demarcação corresponde à identificação dos "limites imanentes" de cada direito. Tais limites, que representam a fronteira externa dos direitos fundamentais, podem estar definidos expressamente na Constituição, ou dela decorrerem implicitamente, sendo, nesse caso, inferidos da análise da proteção outorgada pela 'Lei Maior' a outros direitos e valores da mesma estatura. De qualquer forma, a fixação dos limites imanentes é anterior à resolução dos conflitos, pois só se caracterizará o conflito se a situação concreta se contiver no interior dos limites imanentes de mais de uma norma constitucional (SARMENTO, 2003, p. 100).

É certo que a estrutura aberta e flexível dos princípios, que não possuem um campo de incidência rigidamente delimitado, torna por vezes muito árdua, senão impossível, a tarefa de estabelecer a priori as fronteiras dos seus âmbitos normativos com seus congêneres. Por isso, a análise do caso concreto revela-se freqüentemente essencial para a verificação da existência ou não do conflito entre os princípios constitucionais em jogo. Em muitos casos, o trabalho do intérprete se estancará nesta fase, diante da constatação de que não se está presente diante de uma verdadeira tensão principiológica (SARMENTO, 2003, p. 102).

Entretanto, se na interpretação dos princípios envolvidos no caso em concreto resultar a constatação de uma efetiva colisão, deve-se passar à segunda fase do processo, que envolve a ponderação propriamente dita entre os interesses em disputa. O exegeta ao constatar que determinada hipótese fática é de fato tutelada por dois princípios constitucionais divergentes deverá, à luz das circunstâncias concretas, impor restrições recíprocas sobre os interesses protegidos pelos princípios em disputa, objetivando a acomodação de ambos, onde essa restrição a cada interesse seja a mínima e indispensável convivência de ambos.

Simplificadamente, é possível descrever a estrutura da ponderação como um processo em três etapas. Na primeira fase, são identificados os 
comandos normativos ou as normas relevantes em conflito. Observa-se que, algumas vezes, o conflito se estabelece mais claramente não entre disposições constantes do ordenamento jurídico, mas entre interesses que se opõem, quando, então, será preciso verificar se esses interesses podem ser reconduzidos a normas jurídicas. No caso de normas infraconstitucionais cuja constitucionalidade esteja em disputa por força da incidência de normas constitucionais diversas, que aparentemente indicam conclusões contraditórias, o processo se desenvolve de forma semelhante: todos os elementos devem ser identificados — os que postulam a constitucionalidade da norma e os que sugerem sua inconstitucionalidade para que se possa passar à segunda fase. Ainda na primeira fase, as diversas indicações normativas devem ser agrupadas em função da solução que estejam sugerindo. Ou seja: informações que indicam a mesma solução devem formar um conjunto de argumentos. O propósito desse agrupamento é facilitar o trabalho posterior de comparação entre os elementos normativos em jogo (BARCELLOS, 2003, p. 57).

$\mathrm{Na}$ segunda fase cabe examinar as circunstâncias concretas do caso e suas repercussões sobre os elementos normativos; daí se dizer que a ponderação depende substancialmente do caso concreto e de suas particularidades. A importância que se deverá atribuir a cada um dos elementos normativos indicados na primeira fase depende em boa medida dos fatos. No próximo tópico se estará examinando as duas modalidades de ponderação principais: a levada a cabo em abstrato, a partir da consideração de casos hipotéticos ou situações ocorridas no passado e por meio da qual a doutrina pode sugerir parâmetros racionais ou situações ocorridas no passado e por meio da qual a doutrina pode sugerir parâmetros racionais para a ponderação; e a concreta, desenvolvida pelo aplicador diante de um caso novo e particular. De todo modo, sublinhese que também a ponderação em abstrato é construída com base em fatos (BARCELLOS, 2003, p. 58).

Na terceira fase - a fase de decisão — estará se examinando conjuntamente os diferentes grupos de normas e a repercussão dos fatos sobre eles, a fim de apurar os pesos que devem ser atribuídos aos diferentes elementos em disputa. Diante da distribuição de pesos - esse é o diferencial da ponderação - será possível definir, afinal, o grupo de normas que deve prevalecer. Em seguida, é preciso ainda decidir quão intensamente esse grupo de normas — e a solução por ele indicada 
- deve prevalecer em detrimento dos demais, ou seja: sendo possível graduar a intensidade da solução escolhida, será necessário avaliar qual deve ser o grau apropriado ao caso (ÁVILA apud BARCELLOS, 2003, p. 58). O princípio da proporcionalidade e em especial uma de suas derivações, a vedação do excesso, serão instrumentos importantes nesse ponto (BARCELLOS, 2003, p. 58-59).

Assim, verifica-se que o processo da ponderação de interesses confere ao órgão jurisdicional um poder muito mais amplo do que o usual. Ora, desde a identificação das normas aplicadas ao caso, passando pela seleção dos fatos relevantes, até a escolha geral de pesos e a conclusão, todas as etapas exigem avaliações de caráter subjetivo, que poderão variar em função das circunstâncias pessoais do intérprete e de outras tantas influências sociais.

\subsection{0 princípio da proporcionalidade e a ponderação de interesses}

O princípio da proporcionalidade é essencial para a realização da ponderação de interesses constitucionais, pois o raciocínio que lhe é inerente, em suas três fases subseqüentes, é exatamente aquele que se deve utilizar na ponderação. Na verdade, ponderação e proporcionalidade pressupõem-se reciprocamente, representando duas facetas de uma mesma moeda (SARMENTO, 2003, p. 96).

Segundo Guerra Filho apud Sarmento (2003, p. 96), o princípio da proporcionalidade permite fazer o sopesamento (abwägung, balancing) dos princípios e direitos fundamentais, bem como dos interesses e bens jurídicos em que se expressam, quando se encontrem em estado de contradição, solucionando-a de forma que maximize o respeito de todos os envolvidos no conflito.

O princípio se caracteriza pelo fato de presumir a existência de relação adequada entre um ou vários fins determinados e os meios com quem são levados a cabo. Há violação do princípio da proporcionalidade, com ocorrência de arbítrio, toda vez que os meios destinados a realizar um fim não são por si mesmos apropriados e ou quando a desproporção entre meios e fim é particularmente evidente, ou seja, manifesta (MÜLLER, 1978, p.218).

O princípio da proporcionalidade é direito positivo em nosso ordenamento constitucional. Embora não haja sido ainda formulado como "norma jurídica global", flui do espírito que anima em toda sua extensão e profundidade o parágrafo $2^{\circ}$ do art. $5^{\circ}$, o qual abrange a parte não-escrita 
ou não expressa dos direito e garantias da Constituição, a saber, aqueles direitos e garantias cujo fundamento decorre da natureza do regime, da essência impostergável do Estado de Direito e dos princípios que este consagra e que fazem inviolável a unidade da Constituição (BONAVIDES, 2007, p. 436).

Com efeito, na ponderação, a restrição imposta a cada interesse em jogo, num caso de conflito entre os princípios constitucionais, só se justificará na medida em que: a) mostrar-se apta a garantir a sobrevivência do interesse contraposto; b) não houver solução menos gravosa; c) o benefício logrado com a restrição a um interesse compensar o grau de sacrifício imposto ao interesse antagônico. Assim, a ponderação de interesses se refere a um método de interpretação pautado pelo princípio da proporcionalidade (SARMENTO, 2003, p. 96).

\subsection{O uso da ponderação de interesses na colisão do princípio de acesso ao emprego público versus garantia de proteção contra a despedida arbitrária ou sem justa causa consistente numa indenização}

Como se infere dos estudos retrocitados, a decisão do STF, de considerar inconstitucional a extinção do contrato de trabalho pela aposentadoria voluntária do empregado público, traz um conflito entre o princípio de acesso ao emprego público e o direito à proteção contra a despedida arbitrária ou sem justa causa consistente numa indenização.

Esse conflito acontece porque, ao considerar a não extinção do contrato de trabalho do empregado público aposentado voluntariamente, há uma permissão para acumulação de proventos da aposentadoria do Regime Geral da Previdência Social e da remuneração do emprego público, além de propiciar que o empregado público fique ad eternum no emprego público (pois não há aposentadoria obrigatória para os empregados públicos).

Diante disso, para Barcellos e Barroso (2001, p. 134), deve-se aplicar, a essa colisão de princípios, a ponderação de valores, interesses, bens ou normas constantes em uma técnica de decisão jurídica utilizável nos casos difíceis, que envolvem a aplicação de princípios (ou, excepcionalmente, de regras) que se encontram em linha de colisão, apontando soluções diversas e contraditórias para a questão.

O acesso aos cargos públicos e empregos públicos é um direito fundamental de primeira dimensão, expressivo da cidadania e manifesta- 
ção do princípio da igualdade jurídica, que deve ser abrangente e universal para que todos possam participar da Administração Pública.

A razoabilidade e a proporcionalidade indicam que, na colisão do princípio supracitado com a garantia contra a despedida arbitrária ou sem justa causa consistente numa indenização, deve-se ponderar que a melhor interpretação que preserve ambos os princípios, sem que isso prejudique os seus conteúdos mínimos, é a de que, nos casos de aposentadoria voluntária dos empregados da iniciativa privada, não extingue o contrato de trabalho (valorização do princípio da proteção contra a despedida arbitrária ou sem justa causa) e, nos casos de aposentadoria voluntária dos empregados públicos, o contrato de trabalho deve ser extinto (privilegiando o princípio de acesso ao emprego público, ao possibilitar a outros trabalhadores a ocupação do emprego do aposentado).

O intérprete constitucional, sabedor de que os princípios constitucionais jamais devem ser eliminados mutuamente, ainda quando em colisão ou contradição, cuida de conciliá-los, com maior ênfase do que aquelas dedicadas às regras, que são declaradas inconstitucionais, em geral, com a pronúncia de nulidade (FREITAS, 2001, p. 246-248).

A proporcionalidade também se manifesta como um mandamento de ponderação ou sopesamento (Abwägungsgebot). Vale destacar que, em sua “Teoria Pós-Moderna do Direito”, K. H. Ladeur considera a utilização recorrente da ponderação (Abwägung) a característica mais saliente do paradigma jurídico na atualidade, uma vez que permite oferecer soluções adequadas a cada caso em particular (GUERRA FILHO, 1999, p. 66).

Nota-se, ainda, que os ditames da iniciativa privada não podem ser utilizados em sua totalidade nas empresas públicas e empresas de economia mista, pois sofrem incidência de princípios de ordem pública, como já exposto. Ademais, segundo Lima (2005, p. 2007), as estatais estão sujeitas às regras da licitação (art. 173, III); do concurso público (art. 37, II), ao controle de contas pelos Tribunais de Contas (art. 71, III); seus empregados sujeitam-se à proibição de acumular cargos e empregos (art. 37, XVII); seus servidores sujeitam-se a peculato e corrupção (arts. 312 e 317 do Código Penal); sujeitam-se às regras da improbidade administrativa (art. 37, $4^{\circ}$ da CF e Lei 8.429/92) etc. Portanto, seus empregados sofrem a incidência de todas as regras de Direito Público restritivas, e isso os diferenciam dos trabalhadores da iniciativa privada.

A Administração Pública confere às suas Pessoas Jurídicas Privadas os meios de atuação do Direito Privado, considerados mais adequados 
para a execução de determinadas atividades; mas, simultaneamente, as submete, em parte, ao regime administrativo, na medida considerada essencial para a consecução daqueles mesmos fins. Ou seja, em todas as pessoas de Direito Privado, criadas pelo Estado, existe um traço comum: a derrogação parcial do direito privado por normas de Direito Público (DI PIETRO, 2006, p. 419).

Além disso, o acesso ao emprego público permite uma oxigenação nos quadros da Administração Pública, bem como um incremento no mercado de trabalho, haja vista a grande participação do Poder Público no mercado de trabalho atual (em razão do pequeno crescimento da economia brasileira). ${ }^{1}$

Ressalta-se que a interpretação constitucional é processo tópicosistemático, de maneira que resulta impositivo, no exame dos casos, alcançar solução de equilíbrio entre o formalismo e o pragmatismo, evitando-se soluções unilaterais e rígidas. O intérprete constitucional deve ser o guardião, por excelência, de uma visão proporcional dos elementos constitutiva da 'Carta Maior', não entendida a proporcionalidade apenas como adequação meio/fim. Proporcionalidade significa, sobremodo, que estamos obrigados a sacrificar o mínimo para preservar o máximo de direitos (FREITAS, 2001, p. 246-248).

E mais, a nova interpretação constitucional assenta-se em um modelo de princípios, aplicáveis mediante ponderação, cabendo ao intérprete proceder a interação entre o fato e norma e realizar escolhas fundamentadas, dentro das possibilidades e limites oferecidos pelo sistema jurídico, visando à solução justa do caso concreto (BARCELLOS, 2003, p. 376).

Logo, a solução mais acertada ao presente caso concreto é restringir o mínimo aos princípios conflitantes e preservando os diversos interesses em jogo. Dessa forma, ao considerar a extinção do contrato de trabalho apenas nos casos de aposentadoria voluntária do empregado público e não nos casos dos empregados da iniciativa privada, estarão preservados os dois princípios em conflito, sem que nenhum deles seja descartado, haja vista a razoabilidade e proporcionalidade da medida.

Destaca-se, também, que é vedado acumulação remunerada de cargos, funções ou empregos tanto na Administração Direta e Indireta ou fundacional e, reciprocamente, entre elas, conforme dispõem os incisos

\footnotetext{
1 Em 2004, a Administração Pública representava 4.172.773 postos de empregos no mercado de trabalho (fora os $20 \%$ de postos de trabalho informais da Administração), conforme tabela do PNAD, do Ministério do Trabalho (BRASIL, 2004).
}

A \& C R. de Dir. Administrativo e Constitucional, Belo Horizonte, ano 7, n. 28, p. 83-113, abr./jun. 2007 
XVI e XVII do art. 37, ressalvadas certas hipóteses expressamente arroladas, desde que haja compatibilidade de horários e respeitado o teto de remuneração, a saber: a de dois cargos de professor; a de um cargo de professor com outro técnico ou científico; e a de dois cargos ou empregos privativos de profissionais de saúde, com profissões regulamentadas. (Entre esses cargos técnicos ou científicos acumuláveis com cargo de professor, incluem-se, por expressa dicção constitucional, um cargo de magistrado, conforme prevê do art. 95, parágrafo único, I, e um cargo da carreira do Ministério Público, a teor do art. 128, §5º, II, “d”) (BANDEIRA DE MELLO, 2006, p. 271).

Nesse sentido, verifica-se que a Suprema Corte já decidiu em diversos julgados² sobre a impossibilidade de acumulação de remuneração e proventos, garantindo a restrição a que determinadas pessoas tenham uma remuneração muito elevada.

Todavia, incorreu em equívoco o STF no julgamento da ADIn $n^{\circ}$ 1.770-4, ao entender que a manutenção do empregado público, após a concessão da aposentadoria voluntária pela Previdência Social, não acarretaria acumulação de remuneração com proventos, pois, a conclusão é em sentido contrário: com a permanência no emprego público, após a aposentadoria voluntária, o empregado receberá a remuneração do respectivo emprego e os proventos do INSS.

Desse modo, a extinção do contrato de trabalho do empregado público preservará o acesso das pessoas aos empregos públicos e impedirá acumulação de remuneração do emprego com os proventos da aposentadoria do Regime Geral da Previdência. E mais, possibilitará o acesso ao emprego público a todos os cidadãos e impedirá que ocorra a utilização deste emprego em caráter perpétuo, já que existe apenas a aposentadoria obrigatória para os servidores estatutários (art. 40, § $1^{\circ}$, II da CF/88).

Assim, a melhor exegese dos conflitos em debate é a de que a aposentadoria voluntária extingue apenas o contrato de trabalho do empregado público e não o contrato de trabalho dos trabalhadores da iniciativa privada em geral.

Salienta-se, por fim, que a jurisprudência da Suprema Corte, produzida a partir da Constituição de 1988, tem progressivamente se

\footnotetext{
2 RE 463.028. Órgão julgador: Segunda Turma. Relatora: Ministra Ellen Gracie; Al 484.756-AgR. Relator: Ministro Carlos Velloso. Órgão julgador: Segunda Turma; ADI 1.328, Relatora: Ministra Ellen Gracie; RE 141.376. Relator: Ministro Néri da Silveira. Órgão julgador: Segunda Turma; e RE 197.699. Relator: Ministro Marco Aurélio.
} 
servido da teoria dos princípios, da ponderação de valores e da argumentação. O princípio da razoabilidade funciona como a justa medida de aplicação de qualquer norma, tanto na ponderação feita entre princípios quanto na dosagem dos efeitos das regras (BARCELLOS, 2003, p. 377).

Nesse sentido, apresenta-se a decisão da Corte Constitucional sobre a resolução de conflitos principiológicos através da ponderação de interesses, in verbis:

Meio ambiente. Direito à preservação de sua integridade (cf, art. 225). Prerrogativa qualificada por seu caráter de metaindividualidade. Direito de terceira geração (ou de novíssima dimensão) que consagra o postulado da solidariedade. Necessidade de impedir que a transgressão a esse direito faça irromper, no seio da coletividade, conflitos intergeneracionais. Espaços territoriais especialmente protegidos (cf, art. 225, §1 $1^{\circ}$, III). Alteração e supressão do regime jurídico a eles pertinente. Medidas sujeitas ao princípio constitucional da reserva de lei. Supressão de vegetação em área de preservação permanente. Possibilidade de a Administração Pública, cumpridas as exigências legais, autorizar, licenciar ou permitir obras e/ou atividades nos espaços territoriais protegidos, desde que respeitada, quanto a estes, a integridade dos atributos justificadores do regime de proteção especial. Relações entre economia (cf, art. $3^{\circ}$, II, c/c o art. 170, vi) e ecologia (cf, art. 225). Colisão de direitos fundamentais. Critérios de superação desse estado de tensão entre valores constitucionais relevantes. Os direitos básicos da pessoa humana e as sucessivas gerações (fases ou dimensões) de direitos (RTJ 164/158, 160-161). A questão da precedência do direito à preservação do meio ambiente: uma limitação constitucional explícita à atividade econômica (cf, art. 170, VI). Decisão não referendada. Conseqüente indeferimento do pedido de medida cautelar. a preservação da integridade do meio ambiente: expressão constitucional de um direito fundamental que assiste à generalidade das pessoas. (BRASIL, 2005a). (grifou-se)

\subsection{Possibilidade de modificação de entendimento do STF}

Diante dos argumentos sustentados nos tópicos anteriores, verificase passível de modificação a posição do STF quanto à extinção do contrato de trabalho pela aposentadoria voluntária do empregado público, pois, caso isso não ocorra, o emprego público se tornará quase vitalício, já que não existe a aposentadoria obrigatória aos 70 anos para os empregados públicos (como dos servidores públicos estatutários, art. 40, §1 II da CF/88), dificultando o acesso ao emprego público e permitindo acumulação de proventos (da Previdência Social) e remuneração (do emprego público).

Registre-se, ainda, que o fato do STF ter declarado a inconstitucionalidade do $\S 1^{\circ}$ do art. 453 da CLT (que afirmava que o contrato de trabalho do empregado público era extinto com a aposentadoria voluntária)

A \& C R. de Dir. Administrativo e Constitucional, Belo Horizonte, ano 7, n. 28, p. 83-113, abr./jun. 2007 
não impede que seja declarada a extinção do contrato do empregado público pela aposentadoria voluntária. Isso ocorre porque a continuação no emprego pelo empregado público, após a aposentadoria voluntária, viola o princípio do acesso ao emprego público, que deve prevalecer sobre a garantia de proteção contra a despedida arbitrária ou sem justa causa.

Além disso, o STF, recentemente, modificou seu entendimento em outro tema que diz respeito à competência para o julgamento da ação de indenização por danos morais e patrimoniais decorrentes de acidente de trabalho, quando no julgamento de 22.03.2005³ (Ementa 1: RE-AgR 441038) decidiu que a competência era da Justiça Estadual e, posteriormente, no julgamento de 29.06.2005 (Ementa 2, pág. 47: CC 7204/MG), decidiu que era competência da Justiça do Trabalho.

A seguir, os julgados supracitados da Corte Suprema:

CONSTITUCIONAL. COMPETÊNCIA JUDICANTE EM RAZÃO DA MATÉRIA. AÇÃO DE INDENIZAÇÃO POR DANOS MORAIS E PATRIMONIAIS DECORRENTES DE ACIDENTE DO TRABALHO, PROPOSTA PELO EMPREGADO EM FACE DE SEU (EX-) EMPREGADOR. COMPETÊNCIA DA JUSTIÇA DO TRABALHO. ART. 114 DA MAGNA CARTA. REDAÇÃO ANTERIOR E POSTERIOR À EMENDA CONSTITUCIONAL No 45/04. EVOLUÇÃO DA JURISPRUDÊNCIA DO SUPREMO TRIBUNAL FEDERAL. PROCESSOS EM CURSO NA JUSTIÇA COMUM DOS ESTADOS. IMPERATIVO DE POLÍTICA JUDICIÁRIA. Numa primeira interpretação do inciso I do art. 109 da Carta de Outubro, o Supremo Tribunal Federal entendeu que as ações de indenização por danos morais e patrimoniais decorrentes de acidente do trabalho, ainda que movidas pelo empregado contra seu (ex-) empregador, eram da competência da Justiça comum dos Estados-Membros. 2. Revisando a matéria, porém, o Plenário concluiu que a Lei Republicana de 1988 conferiu tal competência à Justiça do Trabalho. Seja porque o art. 114, já em sua redação originária, assim deixava transparecer, seja porque aquela primeira interpretação do mencionado inciso I do art. 109 estava, em boa verdade, influenciada pela jurisprudência que se firmou na Corte sob a égide das Constituições anteriores. 3. Nada obstante, como imperativo de política judiciária — haja vista o significativo número de ações que já tramitaram e ainda tramitam nas instâncias ordinárias, bem como o relevante interesse social em causa —, o Plenário decidiu, por maioria, que o marco temporal da competência da Justiça trabalhista é o advento da EC 45/04. Emenda que explicitou a competência da Justiça Laboral na matéria em apreço. 4. A nova orientação alcança os processos em trâmite pela Justiça comum estadual, desde que pendentes de julgamento de mérito. É dizer: as ações que tramitam perante a Justiça comum dos Estados, com sentença

\footnotetext{
3 RE-AgR 441038 / MG - Minas Gerais. Órgão Julgador: Segunda Turma. AG. REG. no Recurso Extraordinário. Relator: Ministro Celso de Mello. Julgamento: 22 mar. 2005. Publicação, DJ, p. 000036, 08 abr. 2005. Ementa v. 02186-5, p. 00832.

${ }^{4}$ CC 7204 / MG - Minas Gerais. Conflito de Competência. Órgão Julgador: Tribunal Pleno. Relator: Ministro Carlos Britto. Julgamento: 29 jun. 2005. DJ, p. 0000509, dez. 2005. Ementa v. 02217-2, p. 00303.
} 
de mérito anterior à promulgação da EC 45/04, lá continuam até o trânsito em julgado e correspondente execução. Quanto àquelas cujo mérito ainda não foi apreciado, hão de ser remetidas à Justiça do Trabalho, no estado em que se encontram, com total aproveitamento dos atos praticados até então. A medida se impõe, em razão das características que distinguem a Justiça comum estadual e a Justiça do Trabalho, cujos sistemas recursais, órgãos e instâncias não guardam exata correlação. 5. O Supremo Tribunal Federal, guardião-mor da Constituição Republicana, pode e deve, em prol da segurança jurídica, atribuir eficácia prospectiva às suas decisões, com a delimitação precisa dos respectivos efeitos, toda vez que proceder a revisões de jurisprudência definidora de competência ex ratione materiae. O escopo é preservar os jurisdicionados de alterações jurisprudenciais que ocorram sem mudança formal do Magno Texto. 6. Aplicação do precedente consubstanciado no julgamento do Inquérito 687, Sessão Plenária de 25.08.99, ocasião em que foi cancelada a Súmula 394 do STF, por incompatível com a Constituição de 1988, ressalvadas as decisões proferidas na vigência do verbete. 7. Conflito de competência que se resolve, no caso, com o retorno dos autos ao Tribunal Superior do Trabalho. (grifou-se)

ACIDENTE DO TRABALHO - INDENIZAÇÃO POR DANOS MATERIAIS E/ OU MORAIS - AÇÃO AJUIZADA EM FACE DO EMPREGADOR, COM FUNDAMENTO NO DIREITO COMUM - MATÉRIA QUE, NÃO OBSTANTE A SUPERVENIÊNCIA DA EC 45/2004, AINDA PERMANECE NA ESFERA DE COMPETENNCIA DO PODER JUDICIÁRIO LOCAL - RECURSO IMPROVIDO.

- Compete à Justiça dos Estados-membros e do Distrito Federal, e não à Justiça do Trabalho, o julgamento das ações de indenização por danos materiais elou morais resultantes de acidente do trabalho, ainda que fundadas no direito comum e ajuizadas em face do empregador. - Não obstante a superveniência da EC 45/2004, subsiste integra, na esfera de competência material do Poder Judiciário local, a atribuição para processar e julgar as causas acidentárias, qualquer que seja a condição ostentada pela parte passiva (INSS ou empregador), mesmo que a pretensão jurídica nelas deduzida encontre fundamento no direito comum. Inaplicabilidade da Súmula 736/STF. Precedente: RE 438.639/MG, Rel. p/ o acórdão Min. CEZAR PELUSO (Pleno). (grifou-se)

\section{Conclusão}

Conclui-se que, pela utilização da técnica de ponderação de interesses na hipótese da colisão de princípios constitucionais de acesso ao emprego público (art. 37, I e II da CF/88) e a garantia de proteção contra a despedida arbitrária ou sem justa causa por meio de uma indenização (art. 7, I e art. 10 da ADCT da CF/88), deve prevalecer o princípio do acesso ao emprego público. Por conseqüência, isso possibilitará o acesso ao emprego público a todos os cidadãos, impedindo que ocorra a utilização deste emprego em caráter perpétuo, na medida em que existe somente a aposentadoria obrigatória para os servidores estatutários (art. 40, §1 ${ }^{\circ}$, II da $\mathrm{CF} / 88$ ).

Conclui-se, ainda, que a permanência do empregado público no emprego, após a sua aposentadoria pela Previdência Social, permitirá que haja uma acumulação de remuneração com proventos, que é vedado pela Constituição (arts. 37, XVI, XVII da CF/88) e pelo entendimento do A \& C R. de Dir. Administrativo e Constitucional, Belo Horizonte, ano 7, n. 28, p. 83-113, abr./jun. 2007 


\section{Supremo Tribunal Federal.}

Desse modo, com a aplicação da ponderação de interesses, estará preservado o conteúdo mínimo dos dois princípios analisados, pois a garantia de indenização na despedida arbitrária ou sem justa causa poderá ser aplicada nos casos dos empregados particulares (preservando-se o seu conteúdo) e, nos casos dos empregados públicos, não será utilizada essa norma (preservando-se o conteúdo do princípio de acesso ao cargo público). Ou seja, haverá extinção do contrato de trabalho pela aposentadoria voluntária apenas nos casos dos empregados públicos.

Por fim, sugere-se uma mudança de interpretação por parte do Supremo Tribunal Federal, que deveria concluir pela extinção do contrato de trabalho do empregado público que se aposentar voluntariamente.

\section{Referências}

ALEXY, Robert. A Theory of Constitutional Rights. Oxford University Press, 2002. In: SOUZA NETO, Cláudio Pereira; SARMENTO, Daniel (Org.). A constitucionalização do Direito: fundamentos teóricos e aplicações específicas: Rio de Janeiro: Lumen Juris, 2007.

ÁVILA, Humberto. Teoria dos Princípios apud BARCELLOS, Ana Paula de. Alguns parâmetros normativos para a ponderação de interesses. In: BARROSO, Luís Roberto (Org.). A nova interpretação constitucional: ponderação, direitos fundamentais e Relações Privadas. Rio de Janeiro: Renovar, 2003.

BANDEIRA DE MELLO, Celso Antônio. Curso de direito administrativo. São Paulo: Malheiros, 2006.

BARCELLOS, Ana Paula de. Alguns parâmetros normativos para a ponderação de interesses. In: BARROSO, Luís Roberto, (Org.). A nova interpretação constitucional: ponderação, direitos fundamentais e relações privadas. Rio de Janeiro: Renovar, 2003.

BARCELLOS, Ana Paula de; BARROSO, Luís Roberto. A nova interpretação constitucional: ponderação, argumentação e papel dos princípios. In: GRAU, Eros Roberto; GUERRA FILHO, Willis Santiago (Org.). Direito constitucional: estudos em homenagem a Paulo Bonavides. São Paulo: Malheiros, 2001.

BARCELLOS, Ana Paula de; BARROSO, Luís Roberto. O começo da história. In: BARROSO, Luís Roberto (Org.). A nova interpretação constitucional: ponderação, direitos fundamentais e relações privadas. Rio de Janeiro: Renovar, 2003.

BARROS, Alice Monteiro de. Curso de direito do trabalho. São Paulo: LTr, 2005.

BARROSO, Luís Roberto (Org.). A nova interpretação constitucional: ponderação, direitos fundamentais e relações privadas. Rio de Janeiro: Renovar, 2003.

BARROSO, Luís Roberto. Interpretação e aplicação da Constituição: fundamentos de uma dogmática constitucional transformadora. São Paulo: Saraiva 1996;

BARROSO, Luís Roberto. Neoconstitucionalismo e constitucionalização do direito. In:

SOUZA NETO, Cláudio Pereira; SARMENTO, Daniel (Org.). A constitucionalização do direito: 
fundamentos teóricos e aplicações específicas: Rio de Janeiro, Lumen Juris, 2007.

BARROSO, Luís Roberto. Temas de direito constitucional. Rio de Janeiro: Renovar, 2005. t. 3. BOBBIO, Norberto. Teoria do ordenamento jurídico. Brasília: UnB, 1999.

BONAVIDES, Paulo. Curso de direito constitucional. São Paulo: Malheiros, 2007.

BRASIL. Pesquisa Nacional por Amostra de Domicílios - 2004. Banco de dados do Ministério do Trabalho e do Emprego. Brasília: Ministério do Trabalho e do Emprego. Disponível em //www.mte.gov.br/observatorio/pme_pnad/bancoDeDados/pnad/parte10/tabelas\%20 $10 \_8 . x l s>$.

CARVAlHO FILHO, José dos Santos. Manual de direito administrativo. Rio de Janeiro: Lumen Juris, 2004.

CUNHA JÚNIOR, Dirley da. Controle de constitucionalidade: teoria e prática. Salvador: JusPODIVM, 2006.

DI PIETRO, Maria Sylvia Zanella. Direito administrativo. São Paulo: Atlas, 2006.

FREITAS, Juarez. O intérprete e o poder de dar vida à Constituição: preceitos de exegese constitucional. In: GRAU, Eros Roberto; GUERRA FILHO, Willis Santiago (Org.). Direito constitucional: estudos em homenagem a Paulo Bonavides. São Paulo: Malheiros, 2001.

GASPARINI, Diogenes. Concurso Público e Constituição. In: MOTTA, Fabrício (Org.). Concurso público e Constituição. Belo Horizonte: Fórum, 2005.

GRAU, Eros Roberto; GUERRA FILHO, Willis Santiago (Org.). Direito constitucional: estudos em homenagem a Paulo Bonavides. São Paulo: Malheiros, 2001.

GUERRA FILHO, Willis Santiago. Processo constitucional e direitos fundamentais. São Paulo: Celso Bastos, 1999.

LEITE, George Salomão (Org.). Dos princípios constitucionais. São Paulo: Malheiros, 2003.

LIMA, Francisco Meton Marques de. Elementos de direito do trabalho e processo trabalhista. São Paulo: LTr, 2005.

MOTTA, Fabrício (Org.). Concurso público e Constituição. Belo Horizonte: Fórum, 2005.

MÜLLER, Pierre. "Le príncipe de la proporcionnalité". Zeitschrift für Schweizerisches Recht, Neue Folge, v. 97, fasc. 3, Basel, 1978 apud BONAVIDES, Paulo. Curso de direito constitucional. São Paulo: Malheiros 2007.

PIOVESAN, Flávia. Direitos humanos e o direito constitucional internacional. São Paulo: Max Limonad, 2002.

ROCHA, Cármen Lúcia Antunes. Princípios constitucionais dos servidores públicos. São Paulo: Saraiva, 1999.

SARMENTO, Daniel. A ponderação de interesses na Constituição Federal. Rio de Janeiro: Lumen Juris, 2003.

SILVA, José Afonso da. Aplicabilidade das normas constitucionais. São Paulo: R. dos Tribunais, 1968.

SOUZA NETO, Cláudio Pereira; SARMENTO, Daniel (Org.). A constitucionalização do direito: fundamentos teóricos e aplicações específicas. Rio de Janeiro: Lumen Juris, 2007.

A \& C R. de Dir. Administrativo e Constitucional, Belo Horizonte, ano 7, n. 28, p. 83-113, abr./jun. 2007 
Informação bibliográfica deste texto, conforme a NBR 6023:2002 da Associação Brasileira de Normas Técnicas (ABNT):

BASTOS, Luiz Allende-Toha de Lima. Ponderação de interesses: acesso ao emprego público versus garantia de proteção contra a despedida arbitrária ou sem justa causa consistente numa indenização. Visão crítica sobre o entendimento do Supremo Tribunal Federal, adotado na ADIn n० 1.770-4, a respeito da não extinção do contrato de trabalho do empregado público pela aposentadoria voluntária. A\&C Revista de Direito Administrativo e Constitucional, Belo Horizonte, ano 7, n. 28, p. 83-113, abr.jun. 2007. 